\title{
Perbandingan Variasi Jarak Tempuh ke Sekolah terhadap Prestasi Belajar IPA Siswa Kelas VII SMP Muhammadiyah 2 Kalibawang
}

\author{
Septi Asri Lestari ${ }^{* a}$, Hendro Kusumo EPM ${ }^{* b}$ \\ ${ }^{{ }^{*}}$ Guru IPA SMP Muh 2 Kalibawang, Duwet, Kulonprogo \\ surat elektronik: virgo8163@yahoo.com \\ ${ }^{*}$ Progam Studi Pendidikan Biologi, FKIP, Universitas Ahmad Dahlan \\ Kampus III, Jl. Prof. Dr. Soepomo, SH, Yogyakarta, 55164 Indonesia \\ surat elektronik: pbiouad@gmail.com
}

\begin{abstract}
ABSTRAK
SMP Muhammadiyah 2 Kalibawang, berlokasi di daerah pinggiran kota Yogyakarta tepatnya di Dusun Duwet II, Desa Banjarharjo, Kecamatan Kalibawang, Kabupaten Kulon Progo,dimana jarak tempuh siswa ke sekolah bervariasi dari yang terdekat hingga terjauh. Apakah variasi jarak tempuh ke sekolah dapat menentukan prestasi belajar siswa. Penelitian ini bertujuan untuk mengetahui jarak tempuh ke sekolah dari setiap siswa, dan membandingan variasi jarak tempuh tersebut terhadap prestasi belajar IPA siswa. Prestasi belajar IPA diukur dengan tes, dalam hal ini adalah nilai UAS (Ujian Akhir Sekolah).

Penelitian ini merupakan penelitian deskriptif-kualitatif yang dilakukan di SMP Muhammadiyah 2 Kalibawang dengan teknik dokumentasi dan wawancara kepada siswa sebanyak 24 orang pada Juni 2014 sampai Juli 2015.

Berdasarkan hasil penelitian dapat ditarik kesimpulan bahwa, perbedaaan jarak tempuh ke sekolah setiap siswa tidak menentukan prestasi belajar IPA siswa (siswa kelas VII SMP Muhammadiyah 2). Ada beberapa faktor yang lebih mempengaruhi prestasi siswa, diantaranya motivasi internal siswa, orang tua, serta keadaan ekonomi keluarga.
\end{abstract}

Kata kunci: Jarak tempuh, Prestasi Belajar, SMP Muh 2 Kalibawang

\section{Pendahuluan}

Sekolah merupakan salah satu lembaga pendidikan formal yang dengan sengaja, terarah dan sistematis bertugas menciptakan kesempatan seluas-luasnya kepada setiap individu untuk mengembangkan diri sesuai dengan kemampuannya. Pendidikan memiliki peran penting dalam mencerdaskan bangsa. Proses belajar tidak selalu berhasil, antara siswa yang satu dengan siswa yang lain karena berbagai faktor yang berbeda. Berhasil tidaknya proses belajar mengajar tergantung dari faktorfaktor yang mempengaruhi proses belajar siswa. Pengenalan terhadap faktor-faktor yang mempengaruhi prestasi belajar sangat penting untuk membantu siswa dalam mencapai prestasi belajar yang sebaik-baiknya.

Untuk mencapai prestasi belajar yang baik, banyak faktor yang mempengaruhinya, antaralain; faktor eksternal, meliputi faktor keluarga, faktor sekolah, dan faktor masyarakat. Dari sekian banyak faktor yang harus diperhatikan, tentu tidak ada situasi I00\% yang dapat dilakukan secara keseluruhan dan sempurna. Tetapi berusaha untuk memenuhinya sesempurna mungkin bukanlah faktor yang mustahil untuk dilakukan.

Faktor lingkungan adalah jarak tempat tinggal. Faisal Akbar (2008) menyampaikan tempat tinggal adalah keberadaan siswa bernaung atau tinggal di sebuah rumah seperti kost, rumah orang tua, atau menumpang pada rumah orang lain. Faktor yang mempengaruhi jarak tempuh siswa ke sekolah salah satunya adalah sarana yang digunakan. Jika sarana merupakan kendala bagi daya tempuh jarak, berarti jarak tempat tinggal dapat menggangu proses belajar siswa. Dengan demikian jauh dekatnya jarak dapat menentukan kondisi siswa terutama dalam meraih prestasi belajar. Semakin jauh jarak yang ditempuh siswa dari tempat tinggal ke sekolah maka semakin banyak waktu dan tenaga yang dikeluarkan. Hal ini mengakibatkan waktu yang digunakan untuk belajar semakin berkurang.

SMP Muhammadiyah 2 Kalibawang berada di daerah pinggiran, tepatnya di Dusun Duwet II, Desa Banjarharjo, Kecamatan Kalibawang, Kabupaten Kulon Progo, Yogyakarta. Siswa-siswinya memiliki jarak 
tempuh ke sekolah yang beragam, mulai dari yang terdekat (Ngemplak) hingga yang terjauh dari sekolah (Kalisentul). Selama proses pembelajaran di kelas, siswa cenderung hanya mencatat dan mendengarkan penjelasan guru. Hal ini diduga karena jarak rumah ke sekolah yang terlampau jauh membuat siswa kurang aktif dan bersemangat di dalam kelasnya. Dengan kata lain, apakah siswa yang jarak tempuh ke sekolah jauh dibandingkan dengan yang jarak tempuh ke sekolah lebih dekat memiliki prestasi belajar berbeda. Berdasarkan permasalahan tersebut, maka penelitian ini bertujuan untuk mengetahui jarak tempuh siswa ke sekolah. Kemudian menentukan variasi jarak tempuh satu siswa dengan siswa lain dibandingkan dengan prestasi belajarnya, dalam hal ini nilai UAS.

\section{Metode Penelitian}

Penelitian ini merupakan penelitian deskriptifkualitatif yang dilakukan di SMP Muhammadiyah 2 Kalibawang dengan teknik pengumpulan data melalui dokumentasi dan wawancara kepada siswa. Populasi penelitian sebanyak 24 orang siswa dilakukan pada bulan Juni 2014 sampai bulan Juli 20I5. Instrumen yang digunakan adalah pedoman wawancara dan dokumen otentik, berupa biodata siswa, nilai rapot siswa, dan daftar konseling dari guru BK. Perolehan data jarak tempuh ke sekolah diperoleh dari biodata siswa dan wawancara, sedangkan data prestasi belajar diperoleh dari nilai Ujian Akhir Sekolah (UAS). Perolehan nilai semester gasal dan genap diukur peningkatan/penurunannya, kemudian dibandingkan dengan jarak tempuh ke sekolah. Perbandingan tersebut disajikan dalam bentuk tabel perbandingan. Hasil wawancara dan dokumen-dokumen otentik digunakan juga untuk menganalisis data secara kualitatif.

\section{Hasil dan Pembahasan}

Berdasarkan pengamatan guru IPA/peneliti karena terdapat lokasi rumah ke sekolah yang terlampau jauh, membuat siswa kurang aktif dan bersemangat di dalam kelasnya, atau dengan kata lain siswa mengalami kesulitan belajar. Hal tersebut didorong oleh keadaan sehari-hari siswa terpaksa berjalan kaki, karena kondisi ekonomi keluarga yang kurang memadai untuk memfasilitasi transportasi ke sekolah. Siswa sesampainya di sekolah tersebut sudah dalam keadaan lelah. Dalam keadaan lelah siswa tidak bersemangat mengikuti kegiatan belajar (Sardiman, 20I0).

Berdasarkan pengamatan guru IPA/peneliti karena terdapat lokasi rumah ke sekolah yang terlampau jauh, membuat siswa kurang aktif dan bersemangat di dalam kelasnya, atau dengan kata lain siswa mengalami kesulitan belajar. Hal tersebut didorong oleh keadaan sehari-hari siswa terpaksa berjalan kaki, karena kondisi ekonomi keluarga yang kurang memadai untuk memfasilitasi transportasi ke sekolah. Siswa sesampainya di sekolah tersebut sudah dalam keadaan lelah. Dalam keadaan lelah siswa tidak bersemangat mengikuti kegiatan belajar (Sardiman, 2010).

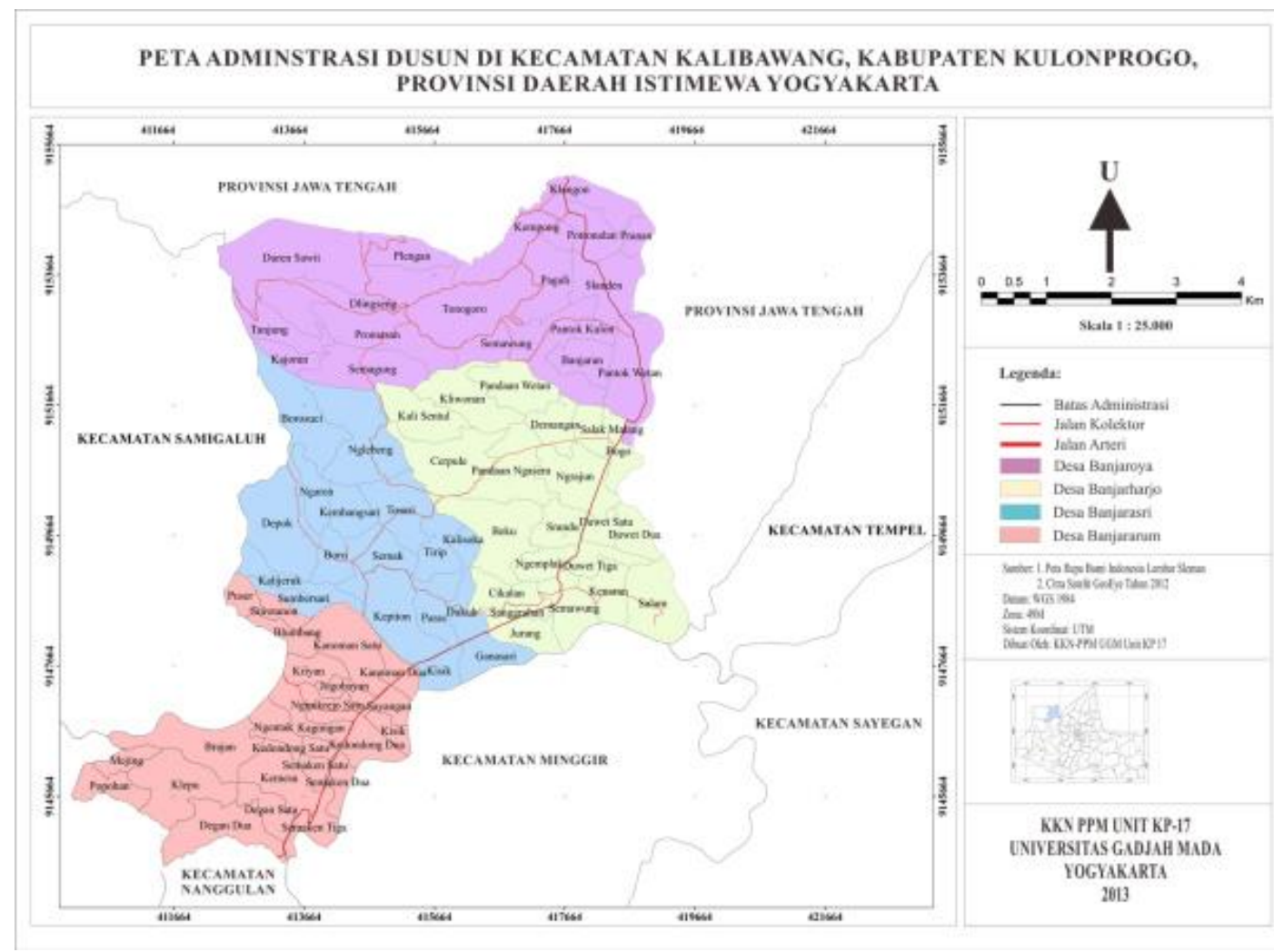

Gambar I. Peta lokasi sekolah terhadap rumah siswa SMP Muh 2 Kalibawang 
Dari peta diperoleh data yang jelas. yakni siswa yang berada di wilayah Kalibawang, yakni Padaan Ngasem terdapat 5 orang siswa,Cikalan 3 orang siswa, Semawung I orang siswa, Selingan I orang siswa, Tirip I orang siswa, Srandu I orang siswa, Demangan I orang siswa, Padaan Wetan I orang siswa, Beji I orang siswa ,Salakmalang I orang siswa, Pantog 2 orang siswa, Ngemplak 2 orang siswa, Sendangsono I orang siswa , dan Kalisentul 2 orang siswa. Di luar Kecamatan Kalibawang yakni Kecamtan Tempel, adalah dari Desa Banyurejo I orang siswa.
Secara keseluruhan kondisi jalan daerah tersebut menuju sekolah dapat ditempuh dengan berjalan kaki maupun kendaraan bermotor, namun akses menuju jalan raya jarang sekali terdapat sarana transportasi umum seperti angkot, sedangkan untuk bis hanya I jam sekali melintas. Untuk melihat perbandingan antar jarak sekolah dengan rumah serta prestasi belajar dalam hal ini nilai Ujian Akhir Sekola diperoleh data berupa berupa tabel jarak tempuh siswa kelas VII SMP Muhammadiyah 2 Kalibawang ke sekolah, yang dibandingkan dengan prestasi belajarnya dari nilai Ujian Akhir Sekolah (UAS).

Tabel I. Lokasi, Jarak tempuh, dan nilai UAS siswa kelas VII SMP Muhammadiyah 2 Kalibawang

\begin{tabular}{|c|c|c|c|c|c|c|}
\hline \multirow{2}{*}{ No } & \multirow{2}{*}{ Nama Siswa } & \multirow{2}{*}{ Lokasi Rumah } & \multirow{2}{*}{ Jarak } & \multicolumn{2}{|c|}{ Nilai UAS } & \multirow{2}{*}{ Keterangan } \\
\hline & & & & Sem Gasal & Sem Genap & \\
\hline 1. & Agus Johan & Padaan Ngasem & $4 \mathrm{Km}$ & 80,85 & 80,00 & Jalan kaki \\
\hline 2. & Apri Isdani & Cikalan & $3 \mathrm{~km}$ & 81,92 & 78,00 & Jalan kaki \\
\hline 3. & Azizah. N & Semawung & $3 \mathrm{~km}$ & 81,50 & 90,00 & Bus \\
\hline 4. & Bayu NF & Selingan & $4 \mathrm{~km}$ & 80,85 & 78,00 & Bus \\
\hline 5. & Bayu NW & Tirip & $4 \mathrm{~km}$ & 80,00 & 90,00 & Bus \\
\hline 6. & Defry. A & Padaan Ngasem & $4 \mathrm{~km}$ & 81,00 & 82,00 & Sepeda \\
\hline 7. & Febri.R & Padaan Ngasem & $4 \mathrm{~km}$ & 80,50 & 80,00 & Jalan kaki \\
\hline 8. & Fitriyana.M & Demangan & $3 \mathrm{~km}$ & 83,75 & 84,00 & Jalankaki \\
\hline 9. & Indayani * & Srandu & $2 \mathrm{Km}$ & 80,00 & 96,00 & Jalan kaki \\
\hline 10. & Kristian R.P & Padaan Wetan & $4 \mathrm{~km}$ & 82,33 & 76,00 & Sepeda \\
\hline 11. & Lesmiyardi $* *$ & Kalisentul & $8 \mathrm{~km}$ & 80,00 & 80,00 & Jalan kaki \\
\hline 12. & M.Jafar Ali ** & Kalisentul & $8 \mathrm{~km}$ & 80,00 & 80,00 & Sepeda \\
\hline 13. & Nurrohmat.N & Beji & $4 \mathrm{~km}$ & 80,00 & 84,00 & Bus \\
\hline 14. & Rachmat.H** & Sendangsono & $6 \mathrm{~km}$ & 80,00 & 78,00 & Bus \\
\hline 15. & Rahmat. H & Salakmalang & $3 \mathrm{~km}$ & 80,00 & 84,00 & Jalan kaki \\
\hline 16. & Ridwan. $\mathrm{P}^{*}$ & Semawung & $2 \mathrm{~km}$ & 80,00 & 86,00 & Jalan kaki \\
\hline 17. & Rohmat .T & Cikalan & $3 \mathrm{~km}$ & 80,00 & 84,00 & Jalan kaki \\
\hline 18. & Siti F.Z & Pantog & $3 \mathrm{~km}$ & 80,00 & 78,00 & Bus \\
\hline 19. & Teguh S.W & Padaan Ngasem & $4 \mathrm{~km}$ & 80,00 & 80,00 & Jalan kaki \\
\hline 20. & Tiwik.O * & Ngemplak & $2 \mathrm{~km}$ & 80,00 & 72,00 & Jalan kaki \\
\hline 21. & Wahyu.R & Banyurejo & $3 \mathrm{~km}$ & 80,42 & 90,00 & Sepeda \\
\hline 22. & Wahyu.S & Cikalan & $3 \mathrm{~km}$ & 81,00 & 72,00 & Sepeda \\
\hline 23. & Wahyu T.I & Padaan Ngasem & $4 \mathrm{~km}$ & 83,00 & 78,00 & Jalan kaki \\
\hline 24. & Aprilia I.S & Pantog & $3 \mathrm{~km}$ & 80,00 & 76,00 & Bus \\
\hline
\end{tabular}

Berdasarkan tabel di atas dapat ditunjukkan bahwa terdapat 3 siswa terjauh yakni Lesmiyardi, M.Jafar Ali, dan Rachmat Hendriawan, sedangkan3 siswa terdekat yakni Indayani, Ridwan Prasetyo, dan Tiwik Oktavia. Rumah Lesmiyardi berjarak $8 \mathrm{~km}$ dari sekolah, dengan menempuh perjalanan pulang-pergi ke sekolah dengan berjalan kaki, namun kadang-kadang diantar jemput oleh orang tua. Hal ini didukung oleh akses jalan yang sudah beraspal, namun keadaan jalan banyak turun naik/tanjakan dan turunan. Waktu tempuh yang dibutuhkan pada saat berjalan kaki kurang lebih 45 ment, sedangkan bila diantar jemput hanya memakan waktu I5 menit. Pada saat berjalan kaki itulah kondisi Lesmiyardi kelelahan setelah sampai disekolah, sehingga semangat belajarnya lemah. Padahal proses belajar dan pembelajaran dipengaruhi oleh kesiapan dan kesehatan subyek didik (Hasibuan \& Moedjiono, 2006).

Muhammad Jafar Ali memiliki jarak rumah ke sekolah adalah $8 \mathrm{~km}$, dengan kondisi jalan beraspal, turun-naik bukit ,ditempuh dengan antar jemput menggunakan kendaraan bermotor, sehingga waktu tempuhnya hanya sekitar I5 menit. Jadi, kondisi fisik Muhammad Jafar Ali masih segar bugar, dengan kata lain bersemangat dalam kegiatan belajar mengajar.

Rachmat Hendriawan berjarak $6 \mathrm{~km}$ dari sekolah menuju rumah, dengan kondisi jalan turun-naik beraspal. Pada waktu ulang-pergi ke sekolah, Racmat Hendriawan menempuh perjalanan dengan bersepeda, dengan memakan waktu sekitar 25 menit. Dengan demikian, maka Rachmat Hendriawan tidak pernah datang terlambat dan semangat mengikuti pelajaran. Namun demikian, Rachmat Hendriawan pernah mengalami kecelakaan, sehingga di semester genap prestasinya sempat menurun akibat sakit yang dideritanya cukup parah selama 2 minggu .

Tiga siswa dengan rumah terdekat yakni; Indayani, Ridwan Prasetyo, dan Tiwik Oktavia masing-masing berjarak $2 \mathrm{~km}$ ke sekolah. Indayani menempuh perjalanan ke sekolah dengan berjalan kaki selama I5 menit. Kondisi jalan beraspal memudahkan Indayani 
pulang-pergi ke sekolah. Dalam kondisi yang segar ini Indayani bersemangat dalam belajar, serta tidak pernah terlambat masuk kelas.

Ridwan Prasetyo bersemangat ke sekolah dan mengikuti pelajaran karena jarak rumah ke sekolahnya hanya $2 \mathrm{~km}$, ditempuh dengan berjalan kaki di atas jalan beraspal tidak banyak turun naik bukit. Semangat belajar Ridwan dan Indayani dikatakan meningkat dari hari ke hari, bahkan muncul kompetisi antara mereka berdua. Hal ini sesuai pendapat Dimyati \& Mudjiono (2009) dan Hasibuan \& Moedjiono (2006) menyebutkan bahwa motivasi internal disebabkan semangat berkompetisi.

Pada siswi bernama Tiwik Oktavia jarak rumahnya ke sekolah hanya $2 \mathrm{~km}$, dengan berjalan kaki selama IO menit menuju ke sekolah dan kondisi jalan beraspal. Namun yang terjadi, Tiwik oktavia sering tidak masuk sekolah khususnya di semester genap, sehingga pelajaran yang seharusnya diikuti tertinggal cukup jauh, khususnya saat pelajaran IPA. Menurut informasi yang diperoleh minat belajarnya turun akibat ingin segera menikah, berhubung usianya yang sudah genap I7 tahun.Hal ini sesuai pendapat Ahmadi dan Supriyono (2004) kesulitan belajar adalah suatu kondisi proses belajar yang ditandai hambatan-hambatan tertentu untuk mencapai hasil belajar. Kesulitan tidak selalu disebabkan faktor intelegensi yang rendah (kelainan mental), akan tetapi dapat juga disebabkan oleh faktor-faktor nonintelegensi. Dengan demikian IQ tinggi belum tentu menjamin keberhasilan belajar.

Faktor-faktor penyebab kesulitan belajar menurut Ahmadi \& Supriyono (2004) yang sudah diketahui ada faktor intern yakni sebab-sebab secara fisik dan secara rohani. Secara fisik menyebabkan sakit, kurang fit/sehat, cacat tubuh. Seseorang yang sakit akan mengalami kelemahan fisiknya, sehingga saraf sensoris dan motorisnya lemah. Akibatnya rangsangan yang diterimanya melalui indra tidak dapat diteruskan ke otak. Anak yang kurang sehat dapat mengalami kesulitan belajar sebab ia mudah capek, mengantuk, pusing, daya konsentrasi hilang, kurang semangat. Hal ini menyebabkan penerimaan dan respon pelajaran berkurang, saraf otak tidak mampu bekerja secara optimal memproses, mengelola, menginterpretasi dan mengorganisasi bahan pelajaran melalui inderanya.

Dari tabel di atas juga dapat diperoleh bahwa tiga siswa mengalami peningkatan belajar dari semester gasal ke semester genap, yaitu Azizah Nurtanti, Indayani dan Wahyu Romadhon.Azizah mencapai nilai 8I,50 di semester gasal dan meningkat menjadi 90,00 di semester genap. Indayani mencapai nilai 80,00 di semester gasal dan meningkat dengan nilai 96,00 disemester genap. Wahyu Romadhon meraih nilai 80,42 di semester gasal dan meningkat menjadi 90,00 di semester genap. Prestasi belajar yang dicapai seorang individu merupakan hasil interaksi antara berbagai faktor yang mempengaruhinya baik dari dalam diri (faktor internal) maupun dari luar diri (faktor eksternal) individu. Faktor internal sangat mempengaruhi belajar siswa namun faktor internal dipengaruhi oleh faktor eksternal. Proses belajar dan pembelajaran dipengaruhi oleh kesiapan dan kesehatan subyek didik (Hasibuan \& Moedjiono, 2006).

\section{Simpulan}

Berdasarkan penelitian yang telah dilakukan, dapat ditarik kesimpulan bahwa jarak tempuh rumah siswa ke sekolah tidak dapat diberbandingkan terhadap prestasi belajar IPA siswa kelas VII SMP Muhammadiyah 2 Kalibawang, tetapi terdapat faktor-faktor lain yang mempengaruhi prestasi belajar siswa,antara lain; motivasi internal siswa, orang tua, serta keadaan ekonomi keluarga.

\section{Daftar Pustaka}

Ahmadi, H.A \& S. Widodo. 2004. Psikologi Belajar. Jakarta: PT.Rineka Cipta.

Akbar, Faisal . 2008. Pengaruh Jarak Tempat Tinggal Terhadap Prestasi Belajar. (Artikel online). http://blogproposal.blogspot.com/2008/I I/pengaruh-jaraktempat-tinggal-terhadap_I6.html.

Dimyati \& Mudjiono. 2009. Belajar dan Pembelajaran. Jakarta : Rineka Cipta.

Hasibuan \& Moedjiono. 2006. Proses Belajar Mengajar. Bandung : PT. Remaja Rosdakarya.

Sardiman. 20I0. Interaksi dan Motivasi Belajar Mengajar. Jakarta : PT. Raja Grafindo Persada. 